参考）住都公団の住まいと緑づくりのながれ

本参考資料は, 住宅・都市整備公団がこれまでに進めてきた街づくり, 住まいづくりのランドスケープについて年代順 にまとめたものである。紙面の関係から, 調查研究成果は公団発行の調査研究期報など刊行物に掲載されたもの, プロジェ クトについてはその時代を代表するあのを中心に選定した。プロジェクトの（）内は特徴的なランドスケープ手法や造 園技術等を記している。

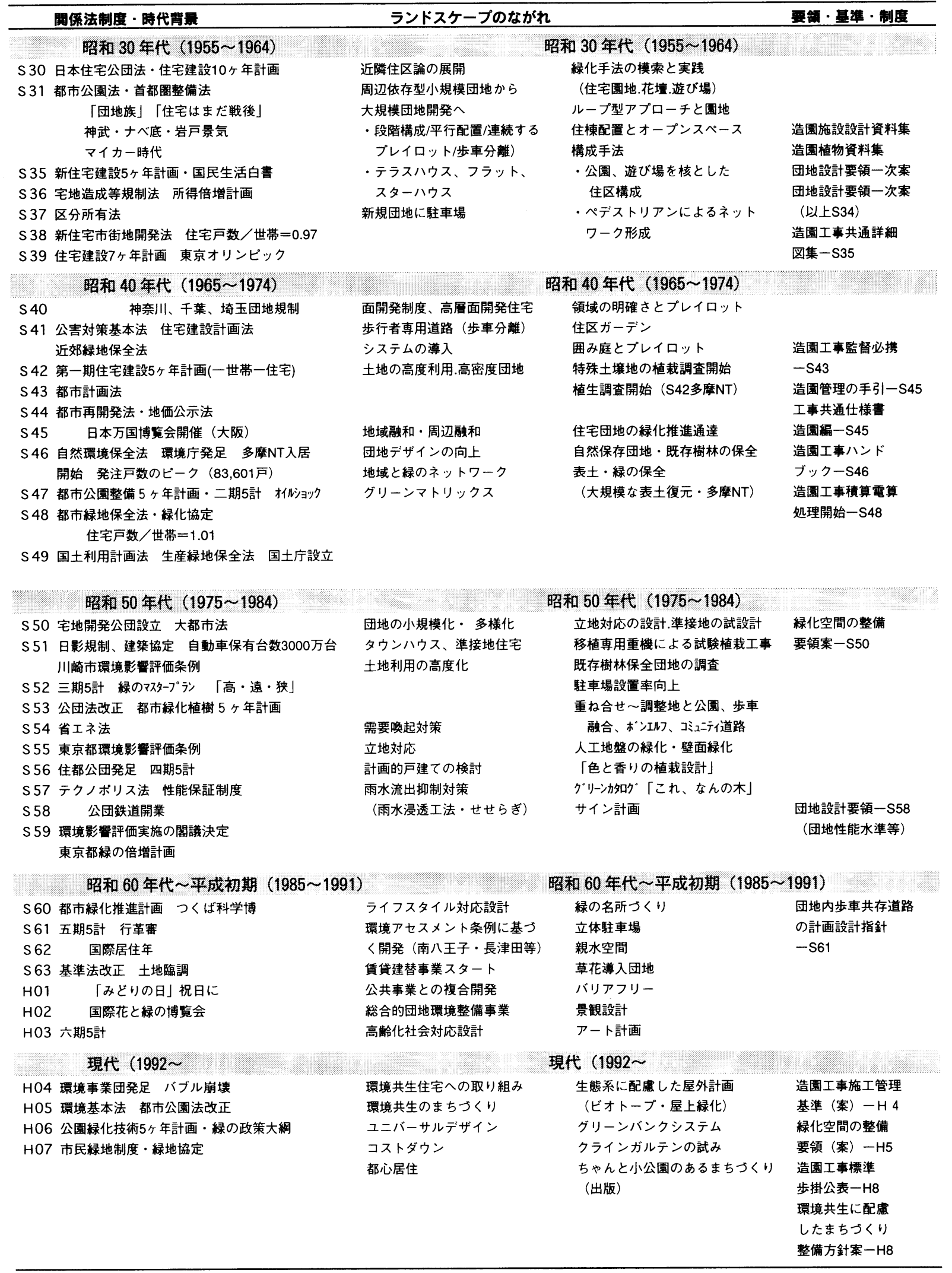


参考文献：

1）（社）日本造園学会編（1978）：造園ハンドブック，技報堂出版

2 ）日本住宅公讨 20 年史刊行委員会編（1981）：日本住宅公団史

3 ）住宅・都市整備公団住宅都市総合研究所（1997）：緑空間等にかかわる今後の展開に関する調査

4 ） ランドスケープ編集会議（1975）：ランドスケープNo.17, 都市計画研究所ランドスケープ出版会

\begin{tabular}{|c|c|}
\hline 代表的プロジェクト & 主な調查研究 \\
\hline \multicolumn{2}{|l|}{ 昭和 30 年代（1955～1964） } \\
\hline 豊田（多摩平団地・近隣住区によるN T 計画）着手 金が作 (常盤平団地) 着手 & 集合住宅団地内空地の緑化方法に関する研究一S30 \\
\hline 香里着手-S30 阿佐ヶ谷団地（遊び場を中心にしたグルーピング） & 団地内児童施設の設置計画に関する研究－S31 \\
\hline 青戸団地（骨格となる桜並木） 前原団地（地形対応とスターハウス） & アパート団地に於ける植裁に関する研究-S33 \\
\hline 多摩平団地（自然と風土の読み取り、既存林を活かす） & 切取盛土面の急速緑化安定工法の研究-S33 \\
\hline ひばりが丘団地（並木の骨格、境界のない遊び場） & 地表面処理植裁に関する研究ーS36 \\
\hline 高蔵寺 NT 着手 $-S 35$ 赤羽台団地（直交配置と広場、専用庭、多様な木 & 児童施設設計の基砹資料（児童の動作寸法計測値）-S38 \\
\hline 高根台団地（地形を生かした空間構成） 東久留米団地（樹林保存・プレイロ & 芝生の薬剤除草についてーS39 \\
\hline
\end{tabular}

草加松原団地（生活機能による段階構成、ペデ） 豊四季団地（土地の可塑性のデザイン）

多摩 NT 着手一S38 神代団地（規格化された遊具ユニット）

津田沼（防潮・防風林／袖ヶ浦団地）小平団地（大型遊具による大規模游び場）

昭和 40 年代 $(1965 \sim 1974)$

高蔵寺NT（歩車道分離、緑化協定等）石神井公園団地（領域性のある屋外空間） 久留米（歩専道/滝山団地） 西上尾第一団地（囲み型とグルービング・既存林） 板橋（緩衝緑地帯の整備/高島平団地）稲毛海岸 3 丁目団地（「見る庭」と「遊び場」） 千葉 NT 着手 $-S 42$ 筑波研究学園都市着手 $-S 43$

港北 NT （グリーンマトリックス）着手一S44 花見川団地（ペデを軸とする遊び場配置） 桜上水団地（クルドサック）村上団地（續衝緑地の公園利用） 小川団地（初の共同菜園）平城 N T（緑道に流九を導入） 北砂 5 丁目 (多機能な屋外設計の出現) 真美ヶ丘 (幅員 $15 \mathrm{~m}$ の歩尃道) 寺田団地（既存樹林の保存と緑のネットワーク）

屋外空間の効果に関する研究（赤羽台団地） $-S 40$ 遊戯施設の使われ方の調查一 540 団地における戸外生活の実態調查（囲み型配置）-S41 遊び場の広がりと利用単位一 $\mathrm{S} 41$ 植栽設計のための基碤的研究一S42 多摩NT植生調查一S42 植栽地管理の実態調查と管理基準についてーS43 団地内幼児遊園設置計画上の問題点 $-S 43$ 開発地域の植生及び景観管理の基礎的研究-S43 硬質粘土地における植栽方法について一S44 宅地開発における既存樹林の保全に関する調査研究一 $\$ 45$ 団地内における步行ルートに関して一S46 住宅団地における高年柃児の戸外生活実態調查一 -546 団地に於けるレクリエーション施設（分区園等）の実態調查一S49 特殊土壊地試験樹木観測調査一 $\mathrm{S} 49$

昭和 50 年代 (1975 1984)

泉北鴨谷台団地（準接地） 館ケ丘団地（N S ペアによる住戸まわり空間設計） 多摩中央公園基本構想競技設計一S52 千葉東南部（おゆみの道・泉谷公園） タウンハウス䯅訪（都市型低層住宅）芝山団地（中水道システム・せせらき） 金沢シーサイドタウン (ウォーターフロント、ストリートファニチュア、サイン計画) 洞峰公園（太陽熱利用温水プール、アリーナ）光が丘パークタウン（步車共存道路） 多摩NT（落合・鹤牧地区基幹空間整備）哲学道公園ハイツ（雨水流出抑制システムと親水施設） 光明池（緑化協定） 森の里（複合多機能都市、緑地60\%、調整地兼用公園） 港北NT（世世らき公園）牛久保西ひかりヶ丘公園他（市民参加型児童公園計画） 多摩ニュータウン南大沢（庭付き中層） つくば（中央公園基本構想競技設計） 昭島つつじが丘ハイツ（透水性舗装） ガーデンハウス和泉みたち山（戸建て地区での緑化協定） 守谷御所が丘（クラスター型計画戸建て）クリーンタウン武藏村山（みち型計画戸建て） 浦和別所ハイッ（中層高密・ボンエルフ）光が丘パークタウン（茶室と茶庭）

昭和 60 年代 平成初期 (1985 1991)

多摩NT貝取山（根株移植工法） リバーサイドともぶち（日本庭園技法の導入） 谷津パークタウン（駐車場 $100 \%$ ・バラ園の再生）小山田桜台団地（千本桜計画） 品川八潮パークタウン (ツツジ山・立体駐車場)

サニーサイドにれの木台 (名所つくり・草花道入)

松伏N Tゆめみ野（親水空間） アーバンみらい東大宮（遊水池と自然環境の復元）

北摂NT平谷川（河川緑地の親水計画）多摩N Tベルコリーヌ南大沢（マスターアーキテクト方式） 高㚘阿武山団地（ビオトープ） 黒川（動植物の移植・移転、ビオトープパーク）

\section{現代 (1992}

多摩N T・長峰杜の一番街（環境共生）南八王子（ホタルの里ビオトープの復元）

ファーレ立川（パブリックアート）武蔵野緑町団地（緑の継承と利活用）

多摩N T・レーベンスガルデン長池（クラインガルテン）

多摩平団地（既存樹林の保存計画）

造園学会特別賞/多摩NTB B 地区ランドスケープ形成とその事業推進 $-\mathrm{H} 4$ 造園学会特別賞・緑の都市賞総理大臣賞/港北 NT グリーンマトリックスーH8 造園学会賞/筑波研究学園都市の「みどりの系」の構築 $-\mathrm{S} 59$ 造園学会賞/高柣市阿武山団地における上の池公園のビオトープ事業の推進 $-\mathrm{H} 8$
宅地造成における表土利用と土㜔改良法の調査研究一 $\mathrm{S} 50$ 宅地開発における緑化協定制度導入に関する研究一S52 住宅地開発における植裁景観の経年变化に関する研究一S56 人工地盤の緑化工法に関する研究一S56

つる植物による建物外壁等の緑化手法に関する研究一 $\mathrm{S} 57$ 特殊土境地における標準土境改良工法に関する研究一S58 住宅団地への日本庭園道入手法の研究一S 58 高密度団地における造園設計手法に関する研究一S59

\author{
こどもの居住環境に関する研究一 $\mathrm{H} 4$ \\ ワイルドフラワーによる緑化マニュアル案ーH 4 \\ 屋上緑化に関する研究一H 5 \\ 步行者専用道路の計画理念と利用実態に関する研究-H 6 \\ 阪神大震災に於ける公園緑地等の災害状況調査一H 7 \\ 多摩N Tにおける緑化と大気熱環境に関する研究一H 7 \\ 都市空間における草花による草地等の緑化に関する調査研究一H 7 \\ 緑のリサイクル技術に関する研究一H 8 \\ 造園設計図書の表現方法の改良に関する研究一H 8
}

